\title{
VOLUNTEERING IN NON-GOVERNMENTAL ORGANIZATIONS AS SOCIAL POLICY EXPRESSION
}

\author{
Arūnas Acus \\ Klaipèda University
}

\begin{abstract}
The article looks into expression of the phenomenon of volunteering in a society, with the focus on the features of voluntary activities in a non-governmental organization (hereinafter - NGO) that provides social services. The article reveals the origins of the NGO and volunteering, discusses the content of NGO activities in the context of social policy. The role of the NGO is analysed with regards to laws of the Republic of Lithuania and the assessment of the changes in legal regulation in the field of voluntary activity is given. The focus on the interconnection between volunteering, social work activities and the activities provided by an NGO allows to model the strategies of how to deal with various social problems with reference to the reduction of social exclusion and strengthening of social community by preparing social workers. Legal regulation of volunteering activities imposes the preconditions for professionalization of NGO activities and more effective implementation of social policy.

KEY WORDS: volunteering activities, social policy, social services, the content of NGO activities, social work, legal regulation.
\end{abstract}

\begin{abstract}
Anotacija
Straipsnyje atskleidžiama savanorystès fenomeno raiška visuomenèje, akcentuojami savanoriškos veiklos ypatumai nevyriausybinėse organizacijoje (toliau - NVO), teikiant socialines paslaugas. Aptariant NVO veiklos turinį socialinės politikos kontekste pristatomos NVO ir savanorystès ištakos. Remiantis Lietuvos Respublikos įstatymais, aptariama NVO galia vertinant teisinio reguliavimo pokyčius vykdant savanorišką veiklą. Sąsajų tarp savanoriškos, socialinio darbo ir NVO veiklos išryškinimas leidžia modeliuoti įvairių socialinių problemų sprendimo strategijas, siekiant mažinti socialinę atskirtị ir puoselèti visuomenès bendruomeniškumą, rengiant socialinius darbuotojus. Teisinis savanorystès reguliavimas sudaro NVO veiklos profesionalizacijos ir veiksmingo socialinès politikos igyvendinimo prielaidas.

PAGRINDINIAI ŽODŽIAI: savanorystė, socialinè politika, socialinės paslaugos, nevyriausybinių organizacijų veiklos turinys, socialinis darbas, teisinis reguliavimas.
\end{abstract}

DOI: http://dx.doi.org/10.15181/tbb.v79i3.1897

\section{Introduction}

The sector of non-governmental organizations in Lithuania has been steadily growing. It has become more effective and therefore has turned to be a competitor to both the public and profit-making private sectors that provide social services. In this context, NGOs can take over the implementation of many functions from the state institutions that deal with provision of social services. The social services can be implemented in a wide range of areas, such as social security, organization of 
socio-cultural activities, education, applied research, crime, suicide and domestic violence prevention, etc. The mentioned areas uncover the social role of the NGO within the strategy for social policy implementation. Professional social workers provide necessary social services at NGOs. However, there is often a shortage of such specialists. Therefore, the involvement of volunteers in NGO activities provides the precondition for professionalization of NGO activities and more efficient provision of social services in this sector. Volunteers, prepared within NGOs, make a significant contribution to the realization of NGO goals and the development of corporate civic citizenship in the society. The performance of volunteers also creates economic value for the society. According to I. Tamutiene and R. Civinskas, it is the economic assessment of the contribution of voluntary activities in the context of the provision of social services, that "can serve as an argument for planning a balanced social policy for the welfare of the country and non-governmental sector" (2012, p. 61).

In recent years the phenomenon of volunteering has been attracting the increasing attention from scientists. The origin of volunteering has been studied by A. Saulaitis, A. Karaliūte (2005), the history of volunteering has been scrutinized by N. Kurapkaitienè (2013), the situation of volunteering in Lithuania has been considered by A. Medišauskaite (2011), and I. Jonutyte $(2007 ; 2000)$ is one of the first researchers who has looked into volunteering as an opportunity for personality development, and I. Jonutytè, D. Rekis (2009) has studied the possibilities of self-education at NGO of young volunteers aged 14-18. The extention of these studies can be found in the work of V. Pruskus (2014), who analyzed the social significance of youth participation in voluntary activities. A. Saulaitis (2010) and J. Sadauskas, I. Leliūgiene (2010) delved into the expression of volunteering and its importance in the community. Ž. Kèrytè's (2010) insights in constructing citizenship in the context of globalization and revealing the dynamism of the role of NGOs in Lithuania shows that NGOs are finding strategies to meet the challenges of social policy. The Law on Volunteering of the Republic of Lithuania (LR savanoriškos veiklos įstatymas, 2011), which regulates the content of volunteering, has opened space for applied voluntary activities. G. Sakalauskas, A. Čepas, S. Nikartas, L. Úselè (2012) analyzed the phenomenon of volunteering with the focus on the probation system, V. Ražnauskaitè, V. Kanušauskaite (2011) revealed the specifics of voluntary activities in social work, O. Šapelyte, A. Rimeikytė, A. D. Gerulaitis (2014) delved into the discourse of the applicability of theories with regard to the solution of social problems. The above mentioned researchers I. Tamutiene and R. Civinskas and others $(2011 ; 2012)$ analyzed the possibilities of economic contribution assessment of voluntary activities in Lithuania. The experience of foreign scientists is also very helpful in understanding the phenomenon of 
volunteering in the international context. D. Lewis and N. Kanji (2009) presented an innovative approach to NGOs in the context of globalization and international humanitarian aid. P. McCloughan, W. H. Batt, M. Costine, D. Scully (2011) explored the interconnection between paid and unpaid work in voluntary activities.

Methodology publications on volunteering opportunities are an important source of information in shaping public opinion on volunteering activities. The NGO Information and Support Center website provides all the necessary information about NGO volunteering activities. Such publications as "Be a Volunteer - Change the World” („Būk savanoris - keisk pasaulị“) informatively present the content and importance of volunteering activities (Kurapkaitienè, Kèžaitė-Jakniūniené, 2011).

The goal of the article is to consider the volunteering phenomenon within the NGO activities in the context of social policy and with regards to the significance of volunteering activities in the provision of social services and the solution of existing social problems in the society. The improvement in the legal regulation of voluntary and NGO activities provides substantial opportunities for this. The method of scientific literature study and analysis of documents has been used to reach the goal identified.

The general characteristics of voluntary activities and NGO functions. Volunteering activities in many European and world countries is a manifestation of corporal civic citizenship and a prerequisite for the implementation of social policy. The Law on Volunteering of the Republic of Lithuania (LR savanoriškos veiklos įstatymas, 2011) describes volunteering as a non-profit-making and freely exercised public benefit activity. It is symbolic that this important document was adopted in the same year that the European Commission announced the Year of Volunteering. The spread of volunteering contributes to corporate civic citizenship and the development of responsibility for every member of the society.

The Law on the Development of Non-Governmental Organizations of the Republic of Lithuania (LR nevyriausybinių organizacijų pletros įstatymas) (2013, Chapter 2) explicitly declares the purpose of the NGO, stating that "a non-governmental organization is a public legal entity acting on the basis of voluntary activity independently of the state or municipal institutions and bodies, with the purpose to pursuit no political power or the realization of solely religious goals". Therefore, it is obvious that volunteering activities are often realized in the non-governmental sector.

N. Kurapkaitiene (2013) in her analysis of the origin of volunteering activities in different countries states that each country has its own specific historical development. The origins of Lithuanian volunteering activities are found in the activities 
of the Catholic Church while caring for the poor, orphans, people in shelters and hospitals. During the inter-war period of Independent Lithuania, there were many non-governmental organizations that responded to people's social needs. In the Soviet period these organizations were replaced by trade unions. The understanding of volunteering activities changed - volunteering became a social activity which could not be identified with voluntary activities. After the restoration of Lithuania Independence, already in 1994 the training of social workers was started, thus their professional activities were inseparable from volunteering activities. It can be stated that they complemented each other. Many volunteers are being trained within the NGOs as there is a great shortage of social work providers. E. Butkevičiene, E. Vaidelyte (2013) reveal the activities of NGOs in different historical periods, presenting their main forms and their legal regulation. Currently, non-governmental organizations operating in Lithuania can be divided into four groups (Fig. 1), and their activities are regulated by respective legal acts, which are applicable to institutions performing public administration functions and which regulate statutes and activities of such organizations. The legal acts are the following: Law on Public Administration of the Republic of Lithuania (LR viešojo administravimo instatymas, 2006), Law on Associations of the Republic of Lithuania (LR asociaciju instatymas, 2004), Law on Charity and Support Funds of the Republic of Lithuania (LR labdaros ir paramos fondu ịstatymas, 1996), Law on Public Institutions of the Republic of Lithuania(LR viešujų ịstaigų ịstatymas, 1996), Law on Voluntary Activities of the Republic of Lithuania(LR savanoriškos veiklos ịstątymas, 2011), Law on the Development of Non-Governmental Organizations of the Republic of Lithuania (LR nevyrisusybinių ịstaigų plètros įstatymas, 2013).

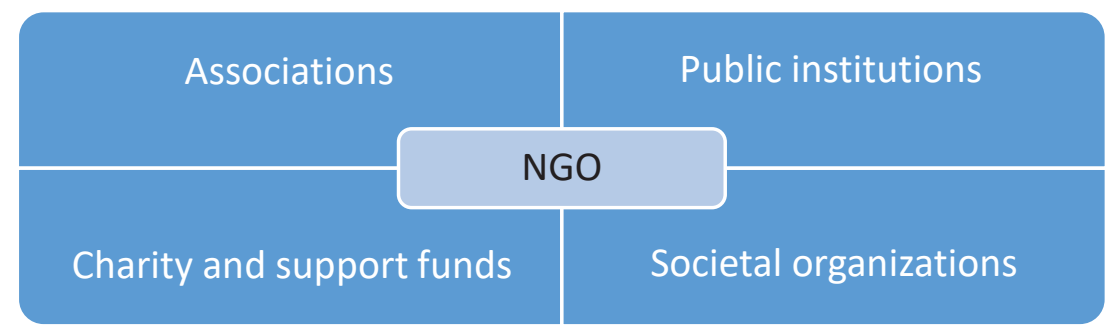

Fig. 1. The forms of non-governmental organizations that are enshrined in the legislation of the Republic of Lithuania

It must be admitted that a much wider variety of NGO forms is found in real life than in the aforementioned legal acts of the Republic of Lithuania. The actual number of NGOs in Lithuania is not known, as it is difficult to distinguish an NGO according to its legal form and the activities performed. The review of the annual 
statistical indicators on the NGOs in cities and towns throughout Lithuania shows that there may be about 18,000 NGOs together with different business unions, associations of professional interests and other organizations that focus on revenue generation. NGOs, whatever their form, respond to various societal challenges: they provide consultancy and information services, organize training, foster social and health care, represent social groups that initiate various actions and campaigns on significant issues with the purpose to change public opinion or legal regulations. According to D. Gineitiene, E. Vaidelytė, A. Vaisvalavičiūtė (2010), NGOs perform many important functions that contribute to the development of the welfare state. The authors assess the significance of NGO activities and distinguish the functions that are provided by NGOs: empowerment, identification of problems, mobilization of human resources, mediation, promotion of changes, monitoring, development of leadership, representation, legitimization, promotion of participation. This is also in line with legal provisions of NGO activities. Pursuant to the laws of the Republic of Lithuania, the functions of non-governmental organizations are precisely and clearly defined. They include provision of services, mutual assistance or self-help, resources and their coordination, representation of interests and active participation in public affairs. The legal certainty ensures a better understanding of the system of NGOs as a whole and gives awareness of the functionality of organizations.

The effectiveness of NGOs also depends on the scope of volunteering activities in them. Volunteering is one of the ways to solve public problems in Lithuania. A volunteer is a person who supports the organization by delivering his/her services, investing time, knowledge and experience without any monetary consideration. In small NGOs, almost all members of the organization become volunteers. Volunteers work in a non-governmental organization does not only bring public benefits. The greatest benefit is gained by NGO members themselves - every person wants to be beneficial to the society, and work for an NGO gives this opportunity to every citizen. A very important aspect of activities in a non-governmental organization is the opportunity to develop one's personal, professional, and special abilities and at the same time affect the implementation of social policy and the development of public welfare. It is difficult for one person to shape the society, yet it is possible to alter or support politicians' decisions if you are working within the organization. Usually NGO's employ relatively few staff members and there is often a shortage of financial resources (Žalimiene, 2006). Therefore, it is necessary to use the available human resources in the form of volunteers. Volunteers bring new ideas to the organization, disseminate information about volunteering activities in society, share good practice. There is a shortage of volunteers who are specialists in different fields. Lawyers, doctors, accountants, artists and designers can tailor 
their experience for the needs of NGOs without any monetary consideration. This is beneficial as many NGOs face difficulties in having to pay for the necessary professional services.

There is a Volunteer Centre in Lithuania which is the first Lithuanian organization that operates in the field of professional volunteering. In 1998 Volunteer Centre was registered as a public institution. The mission of the organization is to support and develop volunteering in Lithuania by providing advice and training to non-governmental organizations on how to work with volunteers, how to promote volunteering as a civic value, how to mediate organizations in finding volunteers. According to I. Jonutyte (2007), the main goal of voluntary activities is the provision of social, pedagogical and psychological assistance to people in helping them to achieve more successful socialization in the community. Volunteering complements the professional assistance, thus the main function of volunteers is to communicate and collaborate with a variety of community-based institutions to empower the community to deliver services more effectively and contribute to social policy. The researchers W. B. Naidich, M. Chisholm (1996) have studied the effectiveness of volunteer assistance. They maintain that voluntary assistance equals the professional assistance.

Public attitudes towards volunteering. G. Sakalauskas and S. Nikartas (2012, p. 20-23) presented the research that was carried out in Lithuania after the Restoration of Independence. The research revealed that in comparison to other countries Lithuania had few people that were involved in volunteering activities. The publication "Volunteering Activities, Statistical Assessment" (Savanoriškas darbas, statistinis vertinimas, 1998) which was issued by NGO Information and Support Centre of Lithuania presents the results of the first survey carried out in Lithuania on the attitudes of Lithuanian residents towards voluntary activities. he research states that there were only 10,074 people in Lithuania who participated in volunteering activities. That made only $5 \%$ of the Lithuanian population. The survey results have also shown that volunteering in Lithuania is very unpopular compared to other countries - the number of US volunteers constituted $50 \%$, in Germany volunteers constituted $20 \%$ of the population and in Hungary this number reached 12\%. In 1998 many people who were involved in the voluntary activities provided social services in discontinuous ways. And only $32 \%$ of volunteers were involved in the provision of social services on regular basis. Women constituted two-thirds of all the volunteers and 23 percent of them were retired. According to T. Brabazon, D. Matisoff, G. Razaitis (1999, p. 3), Lithuanians did not participate in voluntary activities due to the negative attitude of the society towards volunteering activities and the fact that they were not offered voluntary work, i. e. they were 
simply not invited to volunteer in helping organizations to achieve their tasks. This shows the absence of civic initiative in the community.

In 2008, another survey (TNS Gallup) was conducted with the aim to reveal the attitudes of the Lithuanian population towards volunteering. The results of this study were more positive. According to R. Gaudešiene (2008, p. 10-11), 46\% of the Lithuanian population participated in voluntary activities on discontinuous basis, $39 \%$ of the respondents did not participate in volunteering activities at all, but they expressed their willingness to participate, and $15 \%$ of the respondents said that they did not participate and would not like to do that. Many of the respondents stated that they do not have time for volunteering activities. The same statement was identified while in the first survey. The key motives for participation in voluntary activities are traditional. They include a desire to help others (59\%), wish to be required and spend time meaningfully $(30 \%)$, find friends $(20 \%)$, support ideas that share the same values $(19 \%)$.

In 2011, a study by the European Commissions Representation in Lithuania carried out a "Vilmorus" (Public Opinion and Research Center) study on the attitudes of the Lithuanian population towards volunteering. According to A. Medišauskaite (2011, p. 28), who presented the analysis of "Vilmorus" public opinion survey, it can be said that Lithuania has "no volunteering traditions (51\%), there is not enough information on voluntary activities (42\%), 37 percent of the respondents were not aware about what volunteers were doing; and it turned out that school students are not taught to provide assistance and help without monetary consideration (38\%)". The study also revealed the reasons why people do not participate in voluntary activities: they do not have enough time (41\%), they do not have information on volunteering opportunities $(21 \%)$, they have health problems themselves (20\%); 34 percent of the respondents did not participate and did not intend to participate in voluntary activities. The last was the higher percentage than in 2008. The research also confirmed the opinion of the above-mentioned researchers that volunteering in Lithuania is not understood in the context of social policy, children are not introduced to the idea of volunteering, they do not see examples in their close environment, it is not a rule to do good without expecting reward, people lack civic activity and the need for social participation. According to I. Jonutytè, D. Rekis (2009), volunteers experience emotional satisfaction and selfrealization, recognition and friendship, they participate in teams of like-minded people, they gain informal education, understanding, support, training of certain skills and competences. Volunteering activities can become the priority of the state and its people. However, a lot of work and effort is needed to develop people's social responsibility. This proves that voluntary activities and legal regulation of NGOs are a constant challenge for civic society. 
Legal regulation of voluntary activities. The phenomenon of volunteering received world-wide recognition after European Parliament had adopted a Resolution on Volunteering (1983), which declared that voluntary activities were an important part of formation of state policy and thus required creating a legal basis for social guarantees for volunteers. A "Universal Declaration of Volunteering" adopted in 1990 brought attention to the meaning of volunteering and provided groundwork for principles of voluntary activities. In 1997 European Comission declared that voluntary activities had an effect on social, economical and political development of European society. The Treaty of Amsterdam (1997) highlighted the possibility for people of different age groups to engage in voluntary activities abroad, while 2001 was proclaimed as the International Year of Volunteers acknowledging that volunteering enhances democracy and provides moral and social benefits both for volunteers and service receivers. 2004 saw the publishing of "Map of Europe" which besides informing all EU members about the issues of volunteering, also acted as a motivator to engage in voluntary actions. In 2005 the European Volunteer Center issued the Manifesto for Volunteering in Europe highlighting how volunteering should be promoted in EU countries. 2011 was proclaimed the European Year of Voluntary Activities. The above said proves that voluntary activities has become an increasingly acknowledged social and political phenomenon.

Although Lithuania had not introduced any legal acts directly regulating voluntary actions until 2011, according to L. Ūselè and G. Sakalauskas (2012, p. 77), "constitutional principles of self-expression, civil initiative and free choice served as a guarantors for legal recognition of voluntary actions, also there was the Law on Charity and Sponsorship, according to which voluntary actions could be considered as a certain form of charity". Republic of Lithuania Law on Volunteering which defined the scope of voluntary actions was adopted only in August 2011, Article 6 of the Law on Volunteering provides that voluntary actions shall be organized by "charity and sponsorship funds, budget institutions, associations, public institutions, religious organisations, communities and religious centers, subsidiaries and representatives of international public organisations, political parties and trade unions". This law also provides that eligible for volunteering are persons above 14 years of age having obtained a permission of their legal representative. The Law on Volunteering indicates (Article10), that "persons engaged in volunteering are not provided with social, health or life insurance, thus, if not employed or studying, become a risk group of society". However, such situations are extremely rare, as volunteering is a dominating form of leisure activities. Therefore, it may be argued that legal reglamentation of volunteering allows for the development of this phenomenon. This argument is supported by several legal acts which were adopted 
after the aforementioned Law on Volunteering: orders of the Minister of Social Security and Labour of the Republic of Lithuania "Rules on the Reimbursement of Expenses Related to Volunteering" (LR socialinès apsaugos ir darbo ministro ịsakymas „Dèl savanoriškos veiklos išlaidų kompensavimo sąlygų ir tvarkos aprašo patvirtinimo“, 2011), "On National Programme for Youth Volunteering” (Dèl nacionalinès jaunimo savanoriškos veiklos programos patvirtinimo, 2013), order of the Director of the Department of Youth Affairs under the Ministry of Social Security and Labour "Rules on Accreditation of Institutions Organizing Youth Voluntary Actvities" (LR Jaunimo reikalų departamento prie Socialinès ir darbo ministerijos direktoriaus ịsakymas „Jaunimo savanorišką veiklą organizuojančių organizacijų akreditavimo tvarkos patvirtinimas“, 2018). The latter act was also of big importance for the non-governmental sector, because after the Resolution No. 85 of the Government of Republic of Lithuania "On the Conception of the Development of Non-Governmental Organisations" (LR Vyriausybės nutarimas Nr. 85 „Dẻl nevyriausybinių organizacijų plètros koncepcijos patvirtinimo“, 2010) activities of youth organisations were a hot topic. Thus a document of 2018 opened substantial opportunities for the development of youth volunteering and for the establishment of links between social work and volunteering in the context of social policy. This shows that the ideas of many authors (Gruževskis, Šabanovas, 2015; Pruskus, 2014) are becoming reality.

Interconnection between volunteering activities and social work in the context of social policy. According to V. Kavaliauskienè (2005), social work is not considered to be a real professional for several reasons. They include a social worker's limited individual autonomy; the fact that the majority of social workers work for local governmental institutions; they perform a social control function; they execute the state welfare function. The author maintains that social work does not hold a solid theoretical basis, social workers do not possess exceptional skills, and in many European Union countries unskilled people or volunteers are labelled as social workers.

The analysis of the social work as a phenomenon carried out by V. Kavaliauskiene $(2005 ; 2010)$ has revealed that social work without any appropriate motivational approaches would only be a mechanical work. The author recognizes a motivational approach in social work that fosters the need for truth and love for man, the need to help a person in a risk situation, the need to be necessary and even dependent on another; the need for social participation for the well-being of man and society. The distinguished ideas can also be considered as the motivational content of voluntary work. As regards a social worker or a volunteer this motivational content would be incomplete without social worker and volunteer's desire to implement social justice (recognition of human rights and interests) and influence 
positive changes in social policy (ensuring the quality of human life). The implementation of this requires special knowledge and skills. C. Sutton (1999) affirms that social work is a profession which requires to use the knowledge practically and social workers from the outset of their training are taught to become practitioners. Social workers solve complicated relationship situations between people and their social environment. Therefore, according to the author, the purpose of social work is the provision of services to an individual, a family, a group of people or a community and the process enables the implementation of social security strategies. This idea of social and voluntary work functions has also been studied by L. Žalimiene $(2003 ; 2006)$ who considered the practical expression of the realization of social functions in social work. The author distinguished the following functions:

1. Identify social issues and evaluate social needs (collect information on a customer and find out a social problem; make contact with a customer).

2. Plan social support (analyse and evaluate individual problematic situation; design a support plan).

3. Provide the necessary social support (preventive work; provision of information; counselling; initiation of change; provision of help; mediation, representation; coordination; carrying out research support work).

4. Analyze the process of social support and assess the results (summarize and evaluate the change; discuss and evaluate the support model (final results).

5. Improve professional competencies and management (analyze the social environment system; make a positive impact on social systems; develop the concept of social work profession; apply innovations in professional activities; cooperate with social partners; initiate and develop voluntary activities).

An important factor in the implementation of social policy is that one of a social worker's competences is the organization of voluntary activities, therefore it would be appropriate to discuss the phenomenon of volunteering in the context of social work.

Volunteers are a great force that can help in providing and organizing assistance. Volunteering encompasses many areas, and a volunteer can work in various organizations. A social worker can choose and involve volunteers in the support provision process, he/she can decide what tasks should be allocated to a volunteer, he/she introduces volunteers to clients, carries out the supervision of the services in progress, teaches volunteers cooperation skills, provides counselling services and takes responsibility for the activities of volunteers. According N. Kurapkaitienè and J. Sadauskas $(2013$, p. 87), involvement of volunteers gives meaning not 
just to the recipients of assistance, but also to the volunteers, since this activity allows to cross the borders between different groups of society and in this way encourages people to get out of any social dissociation.

As stated in I. Jonutyte's doctoral theses (2000), the UK, French, German and Italian experience demonstrates that the voluntary assistance sector helps to improve the quality of life and addresses economic development and employment issues. Volunteers are the initiators of social work in the community. Social welfare programs are being developed and planned in response to social problems within a society. V. Ražanauskaite, V. Kanušauskaitè, (2008) state that volunteers often play a role of social workers since they provide social assistance to various communities and administer mediation services between professional staff and a customer, but the area of social work activities covers the process of the analysis and solution of different social issues directed at individuals, groups of people and communities. The purpose and content of social work is to help individual people, groups of people and communities to pursue their rights and freedoms and disclose potential powers of an individual, also oppose the concern of governmental institutions to minimize community social services (Jonutyte, 2000). The activities of a social worker focus on assistance to elderly, lonely, sick and disabled people, they relate to activities in Child and Youth Centres, organization of events in cultural and recreational areas, participation in the prevention of abuse and violence against children and women. However, there is a shortage of professionals who can help people in these situations, thus volunteers contribute to the solution of this problem and help those in need on the basis of solidarity.

A virtual information space is very helpful in the development of volunteering activities. The "Volunteer Exchange" has been established and it provides support to people who are looking for volunteers as well as to those who would like to get involved in volunteering activities.

All in all it can be said that a social worker's role is to involve volunteers in the provision of social assistance. Social work institutions aim to attract volunteers in a variety of ways (student placements, various studies related to social group problems, etc.). Many organizations employ volunteers who direct their activities at the improvement of community microclimate, they help to solve the problems and implement social welfare programs. A volunteer in the organization must be viewed as a staff member. NGO plays an exceptionally significant role in the engagement of people in voluntary activities. NGOs put a lot of effort into the volunteer training process. Volunteers very often decide that their vocation is to help people and contribute to the welfare of the society. Thus, they resolve on a social work career. 


\section{Conclusions}

Non-governmental organisations (NGOs) have been analysed from various viewpoints. To quote J. Vorevičienè (2016, p. 49), “one thing is agreed upon: that is a sector of social missions and organisations operating with the aim of ensuring the social welfare of citizens, with other aspects inseparable from social welfare cohesion, solidarity, community spirit, democracy, and public spirit - coming from it".

A non-governmental organisation (NGO) is a democratic organisation founded on the will of citizens which serves the interests of the society or its groups and seeks no profit or direct participation in the government of the state. The most widely known types of NGOs in Lithuania include public organisations, associations, and charity and support foundations. In any country of the world, NGOs form the basis of civil society. NGOs are based on the principles of humanism, therefore they promote public spirit and responsibility for one another through participation in the formation of social policies.

In the organisation of their activity, NGOs rely on voluntary practices. NGOs bring together people, willing and able to express themselves in public life. The phenomenon of volunteering focuses on the solution of the community needs-related problems. The basic expression of voluntary work is the creation of social programmes with the aim of making an impact on the development of the social and economic infrastructure in the context of social policy.

The phenomenon of volunteering is directly related to the professional activity of social work. One of the functions of a social worker is to involve volunteers in the realisation of social assistance in the provision of services. Volunteering makes social work a unique profession. Based on the humanistic philosophy approach, one can argue that social work and volunteering activity are closely related and have a direct impact on societal changes, human interrelationhips, and the implementation of social policies.

The view of our society on volunteering is unsatisfactory. The development of the legal framework has a positive impact on the expression of volunteering and NGOs in the context of social policy.

Government Resoliution No. 85 of Republic of Lithuania "On the Conception of the Development of Non-Governmental Organisations" (LR Vyriausybès nutarimas Nr. 85 „Dèl nevyriausybinių organizacijų plètros koncepcijos patvirtinimo“, 2010) correlated with the "Law on Volunteering" of the Republic of Lithuania (LR savanoriškos veiklos istatymas, 2011) and specified the content of volunteering. Order of the Minister of Social Security and Labour of the Republic of Lithuania "On National Programme for Youth Volunteering" (LR socialinės apsaugos ir 
darbo ministro įsakymas „Dèl nacionalinės jaunimo savarankiškos veiklos patvirtinimo“, 2013), and Order of the Director of the Department of Youth Affairs under the Ministry of Social Security and Labour "Rules of Accreditation of Institutions Organizing Youth Volunteering Activities" (LR Jaunimo reikalų prie Socialinès ir darbo ministerijos direktoriaus įsakymas ,Jaunimo savanorišką veiklą organizuojančių organizacijų akreditavimo tvarkos aprašas", 2018) creates conditions for the expansion of youth volunteering and the establishment of the links between volunteering and social work. The involvement of young people in volunteering is a prerequisite for volunteering taking root both in the NGOs and in the governmental sector. The involvement of broader society in volunteering can also be regarded as a precondition for intergenerational solidarity.

\section{References}

Brabazon, T., Matisoff, D., Ražaitis, G. (1999). Kaip būti geru savanoriu? Vilnius: Savanorių centras.

Butkevičienė, E., Vaidelytė, E. (2013). Nevyriausybinès organizacijos ir jų veikla. Kaunas: Technologija.

Gaudešienè, R. (2008). Savanorystė Lietuvoje visuomenès akimis. Savanorysté Lietuvoje: iššūkiai ir perspektyvos. Tarptautinès konferencijos pranešimų santraukos. Vilnius, p. 10-11.

Gineitienè, D., Vaidelytė, E., Vaisvalavičiūtè, A. (2010). Nevyriausybinių organizacijų ir viešojo sektoriaus squveika. Kaunas: Kauno technologijos universitetas.

Gruževskis, B., Šabanovas, S. (2015). Modernios socialinės raidos samprata. Filosofija. Sociologija, Nr. 26 (4), p. $267-276$.

Jonutytė, I. (2007). Savanorystè socialinio ugdymo sistemoje. Monografija. Klaipėda: Klaipėdos universiteto leidykla

Jonutytè, I., Rekis, D. (2009). 14-18 metų jaunųų savanorių saviugdos galimybès nevyriausybinėse Organizacijose. Socialinis ugdymas, Nr. 8 (19), p. 72-147.

Jonutytė, J. (2000). Savanoriu socialiniu pedagogy rengimas. Daktaro disertacija. Klaipėda: Klaipėdos universiteto leidykla

Kavaliauskienè, V. (2005). Socialinio darbo, kaip pagalbos žmogui profesijos, raidos aspektai. Klaipėda: Klaipèdos universiteto leidykla

Kavaliauskienè, V. (2010). Refleksijos kultūra - socialinio darbuotojo profesinès veiklos raiškos aspektas. Acta Paedagogica Vilnensia, Nr. 25, p. 150-171.

Kèrytė, Ž. (2010). Pilietiškumo konstravimas globalumo kontekste: NVO vaidmens kaita Lietuvoje. Kultūra ir visuomene, Nr. 1 (2), p. 67-83.

Kurapkaitienè, N. (2013). Darbo su savanoriais pagrindai. Vadovėlis. Vilnius: Mykolo Romerio universitetas.

Kurapkaitienė, N., Sadauskas, J. (2013). Savanorystė socialiniame darbe: sąsajos ir įtampos. Jaunujų mokslininku darbai, Nr. 2 (40), p. 83-88.

Kurapkaitienè, N., Këžaitė-Jakniūnienè, M. (2011). Būk savanoris - keisk pasaulį. Tavo savanorystės kelrodis. Vilnius: Europos Komisijos atstovybė Lietuvoje. Prieiga internete: https://ec.europa.eu/lithuania/sites/ lithuania/files/savanorystes_kelrodis.pdf [žiūrèta 2019-03-19].

Lewis, D., Kanji, N. (2009). Non-Governmental Organizations and Development. London and New York: Routledge.

Lietuvos Respublikos jaunimo reikalų departamento prie Socialinės apsaugos ir darbo ministerijos direktoriaus įsakymas „Jaunimo savanorišką veiklą organizuojančių organizacijų akreditavimo tvarkos aprašas", priimtas 2018 m. gruodžio 21 d., Nr. 2V-219 (1.4) (2018). TAR, Nr. 21495.

Lietuvos Respublikos savanoriškos veiklos ịstatymas. (2011). Valstybės žinios, Nr. 86-4142.

Lietuvos Respublikos socialinès apsaugos ir darbo ministro $2011 \mathrm{~m}$. vasario $3 \mathrm{~d}$. ịsakymas „Dèl nevyriausybinio sektoriaus plètros 2011-2013 metų programos patvirtinimo“. (2011). Valstybès žinios, Nr. A1-64. 


\section{Arūnas Acus}

Lietuvos Respublikos socialinès apsaugos ir darbo ministro issakymas Nr. A1-330 „Dèl savanoriškos veiklos išlaidų kompensavimo sąlygų ir tvarkos aprašo patvirtinimo“. (2011). Valstybès žinios, Nr. 94-4451.

Lietuvos Respublikos socialinès apsaugos ir darbo ministro ịsakymas Nr. A1-73 „Dèl Nacionalinès jaunimo savanoriškos veiklos programos patvirtinimo“, priimtas 2013 m. vasario 25 d. (2013). Valstybès žinios, Nr. 22-1100.

Lietuvos Respublikos socialinių paslaugų ịstatymas. (2006). Lietuvos Respublikos socialinių paslaugų ịstatymas. Valstybès žinios, Nr. 17-589.

Lietuvos Respublikos viešojo administravimo įstatymas. (2010). Valstybès žinios, Nr. 60-1945.

Lietuvos Respublikos Vyriausybės nutarimas Nr. 85 „Dẻl nevyriausybinių organizacijų plètros koncepcijos patvirtinimo“. (2010). Valstybès žinios, Nr. 12-566.

McCloughan, P., Batt, W. H., Costine, M., Scully, D. (2011). Second European Quality of Life Survey Participation volunteering and unpaid work. European Foundation for the Improvement of Living and Working Conditions. Dublin: European Foundation for the Improvement of Living and Working Conditions.

Medišauskaitė, A. (2011). Savanoriškos veiklos Lietuvoje apžvalga. The Tiltas Trust. ISBN 978-609-8078-06-0.

Naidich, W. B., Chisholm, M. (1996). Developing Programs for Homelesss and Runaway Youth. New York: Covenant House.

Nevyriausybinių organizacijų informacijos ir paramos centras. (2011). Europoje vyraujančiu savanorystès modeliu analize. Vilnius. Prieiga internete: 418http://www.3sektorius.lt/docs/Savanorystes analize_2011_2013-01-17_15_54_38.pdf [žiūrèta 2019-03-14].

Nevyriausybiniu organizaciju žinomumas ir savanoriška veikla. (2012). Visuomenès nuomonès ir rinkos tyrimų centras Vilmorus. Prieiga internete: http://www.3sektorius.lt/docs/Ataskaita_NVO_zinomumas_ santrauka_20130117_16_00_05.pf. [žiūrèta 2019-03-18].

Pruskus, V. (2014). Jaunimo dalyvavimo savanoriškoje veikloje įtaka socializacijai ir kompetencijų ugdymuisi. Santalka: Filologija, Edukologija / Coactivity: Philology, Educology. ISSN 1822-430X / eISSN 23357711.

Ražanauskaitè, V., Kanušauskaitè, V. (2008). Savanoriška veikla socialinio darbo studijose. Socialinis darbas. Patirtis ir metodai, p. 148-159. ISSN 20290470.

Sadauskas, J., Leliūgienè, I. (2010). Socialinio darbuotojo kompetencijos veikti bendruomenèje struktūra. Socialinis darbas, Nr. 9(2), p. 56-63.

Sakalauskas, G., Čepas, A., Nikartas, S., Ūselè L. (2012). Savanorystè probacijos sistemoje: prielaidos ir galimybès. Vilnius: Teisès institutas.

Sakalauskas, G., Nikartas, S. (2012). Savanorystès tradicija Lietuvoje. Savanorystè probacijos sistemoje: prielaidos ir galimybès. Vilnius: Teisès institutas, p. 19-23.

Ūselè, L., Sakalauskas, G. (2012). Teisiniai savanorystès pagrindai. Savanorysté probacijos sistemoje: prielaidos ir galimybès. Vilnius: Teisès institutas, p. 77-79.

Saulaitis, A. (2010). Savanorystẻs organizavimas bendruomenėje. Socialinis darbas: profesiné veikla, metodai ir klientai. Vilnius: Mykolo Romerio universitetas, p. 223-234.

Saulaitis, A., Karaliūtè, A. (2005). Savanorystè, dora ir bendruomenè. Studento vadovas. D. 2. Kaunas: Marijonų talkininkų centro leidykla.

Savanoryste Lietuvoje: Kas? Kaip? Kur? (2009). TEO LT, AB ir Všs „Savanorių centras“. Prieiga internete: http://www.3sektorius.1t/docs/Kas_kaip_kur_2013-01-15_14_56_14.pdf [žiūrèta 2019-03-19].

Savanoriškas darbas, statistinis vertinimas. (1998). Vilnius: NIP.

Second Biennial Report on Social Services of General Interest. (2010). Report: Study on Social Services of General Interest (2011), SPC - A Voluntary European Quality Framework for Social Services (2010). Prieiga internete: https://ec.europa.eu/social/main.jsp?catId=794\&langId=lt [žiūrèta 2019-02-11].

Sutton, C. (1999). Socialinis darbas, bendruomenés veikla ir psichologija. Vilnius: VU Specialiosios psichologijos laboratorija.

Šapelytė, O., Rimeikytè, A. (2014). Teorijos ir praktikos sąsajos jungtinès II pakopos socialinio darbo studiju programos mokslinès tiriamosios praktikos procese. Teorijų pritaikomumo diskursas. Vilnius.

Tamutienè, I., Civinskas, R. (2012). Savanoriškos veiklos indèlio ekonominis vertinimas Lietuvoje. Taikomoji ekonomika: sisteminiai tyrimai, Nr. 6/1, p. 61-72. VDU.

Tamutienè, I., Civinskas, R., Jarašiūnaitè, G., Baltrušaitis, M. (2011). Nevyriausybinio sektoriaus institucinio tvarumo, savanoriu ìtrankimo, tarpusavio bendradarbiavimo, indèlio ị šalies ūkio augima ir galimybiu plètojimo tyrimo ataskaita. Prieiga internete: esdocs.com/doc/477813/societal-innovations-for-globalgrowth [žiūrèta 2019-03-01]. 
Treaty of Amsterdam amending the Treaty on European Union, the Treaties establishing the European Communities and certain related acts. (1997). Luxembourg: Office for Official Publications of the European Communities.

Towards Social Investment for Growth and Cohesion - including implementing the European Social Fund 20142020. (2013). Biennal Report on Social Services of General Interest. European Comission, Brussels. SWD 40 final. Prieiga internete: https://ec.europa.eu/eip/ageing/library/towards-social-investment-growth-andcohesion-including-implementing-european-social-fund_en [žiūrèta 2019-03-12].

Vorevičienė, J. (2016). Trečiasis sektorius ir socialinè gerovè: nevyriausybinių organizacijų vaidmuo gerovès valstybèje. Kultūra ir visuomenè. Socialiniu tyrimu žurnalas, Nr. 7/2, p. 49-70.

Žalimienè, L. (2003). Socialinès paslaugos. Mokomoji knyga. Vilnius: Vilniaus universiteto Specialiosios psichologijos laboratorija.

Žalimienè, L. (2006). Nauji iššūkiai socialinių paslaugų plètrai - mišrios socialinių paslaugų rinkos kūrimas. STEPP: socialine teorija, empirija, politika ir praktika, Nr. 3, p. 139-147.

Žalimienè, L. (2006). Socialinių paslaugų vadyba: balansavimas tarp socialinio teisingumo ir ekonominio racionalumo. Ekonomika ir vadyba: aktualijos ir perspektyvos, Nr. 1 (6), p. 183-189. VšI Šiaulių universiteto leidykla.

Žalimienè, L., Rimšaitė, E. (2007). Nevyriausybinių organizacijų metamorfozès - nuo labdaringos pagalbos vargšams XVIII amžiuje iki socialinių paslaugų rinkos dalyvio šiuolaikinėje visuomenèje. Socialinis darbas, Nr. 6 (1), p. 83-96. 
